\title{
Population Knowledge and Attitude Toward Emergency Management of Avulsed Permanent Teeth
}

\author{
Gisele Lima Teles ${ }^{1}$, Ellen Pereira Ribeiro ${ }^{1}$, Joana Dourado Martins Cerqueira ${ }^{2}(\mathbb{D}$, Alessandra Castro \\ Alves $^{3}\left(\mathbb{D}\right.$, Erica dos Santos Carvalho ${ }^{1}$
}

'Department of Clinical Dentistry, School of Dentistry, Federal University of Bahia, Salvador, BA, Brazil.
${ }^{2}$ Department of Dentistry, Higher Education Unit of Feira de Santana, Feira de Santana, BA, Brazil.
${ }^{3}$ Department of Social and Pediatric Dentistry, School of Dentistry, Federal University of Bahia, Salvador, BA, Brazil.

Correspondence: Joana Dourado Martins Cerqueira, Rua Quintas do Sol, 20, Parque Ipê, Feira de Santana, Bahia, Brazil. 44055-860. E-mail: martinsjoana_1@hotmail.com

Academic Editor: Catarina Ribeiro Barros de Alencar

Received: 14 October 2020 / Review: 14 January 2021 / Accepted: 06 February 2021

How to cite: Teles GL, Ribeiro EP, Cerqueira JDM, Alves AC, Carvalho ES. Population knowledge and attitude toward emergency management of avulsed permanent teeth. Pesqui Bras Odontopediatria Clín Integr. 2021; $21:$ e0223. https://doi.org/10.1590/pboci.2021.100

\begin{abstract}
Objective: To evaluate the knowledge of patients treated in a public University concerning dental avulsion and its emergency first-aid management. Material and Methods: Three hundred patients were invited to answer a questionnaire about demographic characteristics, attitude and knowledge of first-aid management of dental avulsion. Chi-square test was used to assess the association between knowledge about dental replantation and education level. Results: Female gender (66.7\%) aged from 31 to 40 years (31.3\%) with high school education (50.3\%) predominated among all the participants. It was not found a difference between education level and management of avulsed permanent teeth ( $\mathrm{p}=0.076$ ), and $66 \%$ of the respondents were not able to do the replantation. In relation to the management of avulsed tooth, $42.7 \%$ of the respondents would brush the tooth and if the replantation was not possible, most of them would choose inappropriate media for storage. The association between the storage medium and educational level showed to be statistically significant $(\mathrm{p}=0.043)$. Conclusion: It was possible to notice the lack of knowledge about this subject, and it could result in the worst prognosis. In avulsion cases, the subsequent root resorptions may lead to the loss of the child's tooth. It is important to implement educational campaigns to spread knowledge and improve success rates of permanent avulsed teeth.
\end{abstract}

Keywords: Tooth Injuries; Tooth Avulsion; Tooth Replantation; Community Dentistry. 


\section{Introduction}

Dental trauma has been reported to occur commonly in childhood and adolescence and the vast majority of cases, during physical or recreational activity, especially in schools or at home [1-6]. Thus first aid is usually provided by parents, guardians, or teachers [4,7-9]. The procedures performed at the time of trauma are essential and mandatory to the prognosis and, precisely for this, it is important for people to be aware of how to proceed in avulsion situations and when performing replantation [2-4,6].

An avulsion is a type of trauma characterized by the complete displacement of the tooth of its alveolus. Replantation is known as the first treatment option and, if performed within sixty minutes, periodontal ligament cells are still considered viable, and the prognosis of these avulsion cases is favorable [10]. After this time, the cells become unfeasible and the prognosis becomes poor. If the replantation is not immediate, the tooth should be stored in a physiological medium that preserves the periodontal ligament cells until it can be replanted [1,2,4,6,10-14].

The literature states that Hanks balanced saline solution (HBSS) is one of the best media of cell conservation because it will hardly be available at the time of trauma. Milk is a viable substitute because it is more accessible and contains adequate osmolarity with nutritional substances and growth factors compatible with the maintenance of periodontal ligament cells $[1-3,12,15]$. Another alternative to conserve the avulsed tooth is in the patient's saliva because it has the necessary nutrients, although it has the risk of microbial contamination [1]. Among the undesirable consequences of delayed tooth replantation are external root resorptions, which are related to extra alveolar time and the degree of contamination and damage caused to the periodontal ligament at the time of the accident [2,10].

Some researches indicate that the population's knowledge is, even among dentistry students and dentists, unsatisfactory when related to the conduct towards avulsion [16,17]. The literature shows inadequate results, where the population prefers to keep the tooth in a dry medium, totally compromising the prognosis $[2,4,5]$. Parents and guardians should be aware of the risks in these types of trauma and oriented to intervene with first aid once cases of avulsion occur widely in a family environment. On the other hand, researches show that these characters have unsatisfactory knowledge when asked about avulsion [9,18].

The negative effects of untreated or inappropriate treatment of avulsed permanent teeth such as root resorption and tooth loss can affect esthetics, bone development and psychological consequences. Thus, the present study aimed to evaluate the level of knowledge and attitude of the lay population attended at a Brazilian public university in the face of dental avulsion to implement future potential measures to expand this knowledge.

\section{Material and Methods}

\section{Study Design}

A cross-sectional descriptive study was conducted with a convenience sampling method consisting of the population attended at the Dental School of the Federal University of Bahia (FOUFBA) from September 2018 to October 2019.

\section{Sample and Data Collection}

Three hundred questionnaires were applied with 12 objective questions about the knowledge of dental avulsion and the emergency conducts to be taken by the studied population. All patients over 18 years old attended at the college during the mentioned period, or their companions were included. 
The preparation of the questionnaire was based on existing studies already validated in the literature [1-4,16]. This instrument consisted of two parts: In the first part, data were obtained to characterize the sample (age, gender and educational level) and the second part about the knowledge and emergency attitude towards dental avulsion.

The questionnaire was previously tested with 30 participants to verify problems related to understanding dubious questions; however, there was no need for alteration in the questionnaire. The nature and purpose of the questionnaires were explained to the participants. Each question had multiple choices and the participants were instructed to indicate the ones they thought were correct. The application of all questionnaires was made by a previously trained dentistry academic in the waiting rooms of outpatient clinics.

\section{Data Analysis}

The analyses were performed using the Statistical Package for the Social Sciences (SPSS), version 20 (IBM Corp., Chicago, IL, USA). The Chi-square test was used to assess the association between knowledge about dental replantation and education level. A significance level of $95 \%$ was considered.

\section{Ethical Clearance}

This study was approved by the local Ethics Committee (No. 11939412.5.0000.5024) and those involved authorized their participation through the Informed Consent Form.

\section{Results}

The demographic data indicated that the mean age was of $39.4( \pm 1.0)$ years (minimum age of 18 years and maximum of 78 years), with the most prevalent age group being 31 to 40 years old (31.3\%). Most of the interviewees $(66.7 \%)$ were female and had a high level of education (60.9\%) (Table 1).

\begin{tabular}{|c|c|}
\hline Variables & $\mathbf{N}(\%)$ \\
\hline \multicolumn{2}{|l|}{ Age (Years) } \\
\hline $18-20$ & $18(6.0)$ \\
\hline $21-30$ & $66(22.0)$ \\
\hline $31-40$ & $94(31.3)$ \\
\hline $41-50$ & $54(18.0)$ \\
\hline $51-60$ & $47(15.7)$ \\
\hline $61-70$ & $18(6.0)$ \\
\hline $71-80$ & $3(1.0)$ \\
\hline \multicolumn{2}{|l|}{ Gender } \\
\hline Male & $100(33.3)$ \\
\hline Female & $200(66.7)$ \\
\hline \multicolumn{2}{|l|}{ Education Level } \\
\hline Low Education Level & $117(39.1)$ \\
\hline High Schooling & $183(60.9)$ \\
\hline Total & $300(100.0)$ \\
\hline
\end{tabular}

The questions in the second part of the questionnaire, together with the distribution of responses on the management of avulsed permanent teeth, are shown in Table 2.

With regard to replantation at the time of the trauma, $198(66 \%)$ reported that they would not do it, while $102(34 \%)$ would do the replantation if they were aware that this would be the correct conduct. Before 
replantation, $227(75.7 \%)$ patients answered that they would wash the tooth and most of them $(38.6 \%)$ would wash it with water and rub the tooth during cleaning (42.7\%).

A total of 101 patients $(33.8 \%)$ replied that they would store the tooth wrapped only in paper or cotton; however, other storage media were indicated, such as Water (32.3\%), Saline solution (21\%), Alcohol $(8.3 \%)$, Milk (2.3\%) and Saliva (2.3\%). When associating the storage medium and the level of education, a statistically significant difference was observed $(\mathrm{p}=0.043)$. Many patients $(43.3 \%)$ did not know how long the tooth could be out of the mouth and $25.3 \%$ answered that they could be out of the socket until one day.

Table 2. Distribution of responses on emergency care of dental avulsion.

\begin{tabular}{|c|c|}
\hline Questions & $\mathbf{N}(\%)$ \\
\hline \multicolumn{2}{|l|}{ Have you suffered any dental trauma? } \\
\hline Yes & $45(15.0)$ \\
\hline No & $250(83.3)$ \\
\hline Ignore & $5(1.7)$ \\
\hline \multicolumn{2}{|c|}{ Do you know someone who has suffered dental trauma? } \\
\hline Yes & $123(41.0)$ \\
\hline No & $171(57.0)$ \\
\hline Ignore & $6(2.0)$ \\
\hline \multicolumn{2}{|c|}{ Do you Know that the avulsion treatment is dental replantation? } \\
\hline Yes & $59(19.7)$ \\
\hline No & $241(80.3)$ \\
\hline \multicolumn{2}{|l|}{ Would you do the dental replantation? } \\
\hline Yes & $102(34.0)$ \\
\hline No & $198(66.0)$ \\
\hline \multicolumn{2}{|l|}{ Would you wash the tooth before replantation it? } \\
\hline Yes & $227(75.7)$ \\
\hline No & $73(24.3)$ \\
\hline \multicolumn{2}{|l|}{ What would you wash the tooth with? } \\
\hline Water & $87(38.6)$ \\
\hline Saline solution & $53(23.6)$ \\
\hline Alcohol & $20(8.9)$ \\
\hline Water and soap & $13(5.8)$ \\
\hline Dentifrice & $21(9.3)$ \\
\hline Mouthrinse & $15(6.7)$ \\
\hline Ignore & $16(7.1)$ \\
\hline \multicolumn{2}{|l|}{ Scrub the tooth to clean? } \\
\hline Yes & $97(42.7)$ \\
\hline No & $74(32.6)$ \\
\hline Ignore & $56(24.7)$ \\
\hline \multicolumn{2}{|c|}{ Not redeploying on time would take, which medium for the dentist? } \\
\hline Water & $97(32.3)$ \\
\hline Milk & $7(2.3)$ \\
\hline Saliva & $7(2.3)$ \\
\hline Alcohol & $25(8.3)$ \\
\hline Saline solution & $63(21.0)$ \\
\hline Wrapped in paper or cotton & $101(33.8)$ \\
\hline \multicolumn{2}{|l|}{ How long can the tooth stay out of the mouth? } \\
\hline Half an hour & $47(15.7)$ \\
\hline Five hours & $26(8.7)$ \\
\hline One day & $76(25.3)$ \\
\hline Up to week & $10(3.3)$ \\
\hline Time does not interfere & $11(3.7)$ \\
\hline Ignore & $130(43.3)$ \\
\hline
\end{tabular}

A total of $80.3 \%$ of the respondents did not know that replantation should be performed and only 59 (19.7\%) were aware of the need for replantation. Proceeding on this track, the individual's level of education did 
not influence the knowledge about this procedure because only a few participants with low education level $(18.8 \%)$ and with high education level (20.2\%) affirmed that the avulsion treatment was the dental replantation $(\mathrm{p}=0.076)$.

\section{Discussion}

An avulsion is a type of severe trauma that can bring serious damage to the dental structure and has an occurrence rate that varies around $16 \%$ of dental trauma in permanent dentition [10,13,18-20]. The loss of a tooth due to avulsion can bring sequelae with functional, aesthetic and even psychosocial complications. Some procedures done at the time of the trauma can greatly interfere with the prognosis, such as immediate replantation or storage in an appropriate medium [2,4,11-13,21]. Nevertheless, some studies have shown that the general population, and even health professionals, do not have sufficient knowledge about the management of avulsed teeth $[5,8,14,16,19,21]$.

The immediate treatment for an avulsed permanent tooth is replantation, that is, it's repositioning in the alveolus to minimize damage to the cells of the periodontal ligament, maintain the aesthetic and phonetic function, and in the case of children and adolescents, allow bone development is normally completed $[2,6,10,11,22]$.

Although access to information is facilitated due to technological resources, the interviewees of this study did not present sufficient knowledge on the subject, since most did not know that the treatment of avulsion of a permanent tooth would be the replantation, regardless of the education level being low or high $(p=0.076)$. Other studies have also proven this and justify that the fright and despair caused at the time of the trauma, the lacerated tissues and the presence of pain and blood are some of the reasons why they chose not to do the replantation procedure on their own [2,9,18,21]. Before replantation, if the tooth is dirty, rinse it gently in milk, saline, or in the patient's saliva and replant or return it to its original position in the jaw; however, the root of an avulsed tooth must not be handled to avoid new injuries to the periodontal remnants $[2,4,10,12,16]$. In this research, $75.7 \%$ of the patients reported that they would wash the tooth, considering $38.6 \%$ with water and $23.6 \%$ with saline. In addition, $42.7 \%$ considered it important to rub the tooth during this cleaning. These results corroborate the findings in other studies, which showed that the population did not have correct knowledge about cleaning and handling avulsed teeth [2,21].

If replantation cannot be done immediately, the International Dental Traumatology Association (IADT) recommends that this tooth must be stored in a humid environment with adequate osmolarity to preserve the cells of the periodontal ligament until the nearest dental service, such as milk, HBSS, saliva or saline $[1,10,12,15,16]$. Contrary to this recommendation, most of the participants in this study chose to transport the avulsed tooth wrapped in paper/cotton (dry medium) or other inappropriate media such as alcohol and water. This finding was statistically significant when associated with educational level $(p=0.043)$. These inadequate media make the periodontal ligament cells unviable, increasing the probability of external root resorption and even tooth loss $[1-4,6,13,14,16]$. Some studies have reported that ligament cells preserved in milk for 30 to 60 minutes were quantitatively viable, proving their effectiveness, in addition to their accessibility [1,9,20,21]. However, in this study, only $2.3 \%$ of respondents opted for the milk that is easy, accessible and with good results.

A significant portion of respondents $(32.3 \%)$ would choose to keep the tooth in a bottle with water, which is not considered a good storage medium because of its low osmolarity $[1,12,15,16]$. Saliva is another option for the storage of these teeth because it is a biological medium; however, it has not been considered an 
effective medium because it contains enzymes and bacteria capable of harming cells more than conserving them $[1,2,12,15,16]$. About the time that an avulsed tooth can remain out of the mouth, $43.3 \%$ reported not knowing and $25.3 \%$ believed that it could remain for up to one day, in the same way, that other studies have also demonstrated this ignorance [2,19]. It has been shown that if the extra-oral dry time is less than sixty minutes, the tooth replantation can have a very high percentage of success; however, more than this time, the periodontal ligament cells lose their vitality and this percentage decreases considerably [4,10,1 1,13,20,21].

The occurrence of complications after avulsion such as external root resorption, ankylosis and even tooth loss can be minimized if replantation is performed correctly and immediately; however, it is observed that even some health professionals and first responders do not receive enough information on how to proceed with an avulsion $[4,5,19]$.

Some researchers have evaluated the positive impact of leaflets and lectures to clarify the population about traumatic dental injuries [7,14,20]; however, these actions need to be expanded and generalized. In view of the above, there is a need to implement campaigns and continuing education programs that constantly reinforce the emergency and preventive protocols for dental avulsions, both at school level and at universities, as well as more comprehensive government programs for the population.

\section{Conclusion}

The knowledge of the population analyzed on how to proceed with a dental avulsion is inadequate, resulting in late complications that would compromise the survival of the tooth in the patient's mouth. This indicates the imminent need for collective clarification campaigns to improve the prognosis of tooth avulsion.

\section{Authors' Contributions}

\begin{tabular}{|c|c|c|c|}
\hline GLT & (iD) & --- & Conceptualization, Methodology, Investigation, Data Curation and Writing - Original Draft. \\
\hline EPR & (iD) & --- & Conceptualization, Methodology, Data Curation and Writing - Original Draft. \\
\hline JDMC & (iD) & https://orcid.org/0000-0001-8606-0220 & Conceptualization, Writing - Original Draft and Writing - Review and Editing. \\
\hline $\mathrm{ACA}$ & (iD) & https://orcid.org/0000-0001-6216-9483 & Conceptualization, Methodology, Writing - Original Draft and Writing - Review and Editing. \\
\hline $\mathrm{ESC}$ & (iD) & -- & $\begin{array}{l}\text { Conceptualization, Methodology, Formal AnalysisData Curation, Writing - Original Draft and } \\
\text { Writing - Review and Editing. }\end{array}$ \\
\hline
\end{tabular}

\section{Financial Support}

None.

\section{Conflict of Interest}

The authors declare no conflicts of interest.

\section{Data Availability}

The data used to support the findings of this study can be made available upon request to the corresponding author.

\section{References}

[1] Adnan S, Lone MM, Khan FR, Hussain SM, Nagi SE. Which is the most recommended medium for the storage and transport of avulsed teeth? A systematic review. Dent Traumatol 2018; 34(2):59-70. https://doi.org/10.1111/edt.12382

[2] Albuquerque YE, Rosell FL, Tagliaferro EPS, Silva SRC. Knowledge of mothers about emergency management of tooth avulsion. RFO UPF 2014; 19(2):159-65.

[3] Antunes LAA, Souza HMR, Gonçalves PHPQ, Crespo MA, Antunes LS. Dental trauma and mouthguard: knowledge and attitudes in Physical Education undergraduates. Rev Bras Educ Fís Esporte 2016; 30(2):287-94. https://doi.org/10.1590/1807-55092016000200287 
[4] Costa LED, Queiroz FS, Nóbrega CBC, Leite MS, Nóbrega WFS, Almeida ER. Dental trauma in childhood: evaluation action of educators in public nurseries from the city of Patos-PB. Rev odontol UNESP 2014; 43(6):402-8. https://doi.org/10.1590/1807-2577.1053

[5] Fujita Y, Shiono Y, Maki K. Knowledge of emergency management of avulsed tooth among Japanese dental students. BMC Oral Health 2014; 14:34. https://doi.org/10.1186/1472-6831-14-34

[6] Mesquita GC, Soares PBF, Moura CCG, Roscoe MG, Paiva SM, Soares CJ. A 12-year retrospective study of avulsion cases in a public Brazilian dental trauma service. Braz Dent J 2017; 28(6):749-56. https://doi.org/10.1590/0103-6440201701610

[7] Frítola M, Couto ACF, Spinardi D, Junkes MC, Fraiz FC, Ferreira FM. Do educational leaflets improve the knowledge of parents when faced with traumatic dental injuries? Arq Odontol 2014; 50(4):178-84.

[8] Ningthoujam S, Gurunathan D, Singh WR, Mall BB. Parental self-perceived knowledge and attitudes toward emergency management of avulsed permanent teeth in Imphal: A cross-sectional study. Natl J Maxillofac Surg 2019; 10(1):33-42. https://doi.org/10.4103/njms.NJMS_64_17

[9] Parra Enríquez S, Crespo CL, Bauzá BX, Aguilera OFM. Level of knowledge in parents and educators on the behavior to follow for dental-alveolar traumatisms. CCM 2017; 21(3):820-32.

[10] Fouad AF, Abbott PV, Tsilingaridis G, Cohenca N, Lauridsen E, Bourguignon C, et al. International Association of Dental Traumatology guidelines for the management of traumatic dental injuries: 2. Avulsion of permanent teeth. Dent Traumatol 2020; 36(4):331-42. https://doi.org/10.1111/edt.12573

[11] Balestrin A, Santos MS, Cançado MN, Rafagnin GD. Clinical protocol for the management of avulsion of permanent teeth. Rev Bras Odontol 2018; 75:e1071. https://doi.org/10.18363/rbo.v75.2018.e1071

[12] Longo DL, Fumes AC, Kuchler EC, Paula-Silva FWG, Nelson-Filho P, Silva LAB. Efficiency of diferente storage media for avulsed teeth in animal models: a systematic review. Dent Traumatol 2018; 34(1):12-9. https://doi.org/10.1111/edt.12365

[13] Pujita C, Nuvvula S, Shilpa G, NirmalaS, Yamini V. Informative promotional outcome on school teachers' knowledge about emergency management of dental trauma. J Conserv Dent 2013; 16(1):21-7. https://doi.org/10.4103/0972-0707.105293

[14] Lubaszewski VPA, Raldi DP, Pinto CA, Habitante SM. Evaluation of the emergency procedure used by professionals in cases of dental avulsion before and after educational lectures. ClipeOdonto. 2015; 7(1):9-19.

[15] Poi WR, Sonoda CK, Martins CM, Melo ME, Pellizzer EP, Mendonça MR, et al. Storage media for avulsed teeth: a literature review. Braz Dent J 2013; 24(5):437-45. https://doi.org/10.1590/0103-6440201302297

[16] Santos LCA, Teixeira BCS, Trindade RA, Figueiredo NBM, Carvalho ES. Dental community's knowledge regarding teeth avulsion. J Dent Pub H 2018; 9(1):33-9. https://doi.org/10.17267/2596-3368dentistry.v9i1.1711

[17] Buldur B, Kapdan A. Factors Associated with knowledge and attitude of management of traumatic dental injuries: A cross sectional study among Turkish Dentists. Pesqui Bras Odontopediatria Clin Integr 2018; 18(1):e3948. https://doi.org/10.4034/PBOCI.2018.181.30.

[18] Oliveira MJL, Dias VO, Santos KKF, Rodruigues QF, Paiva ER, Martins RC. Knowledge of dental trauma of parents/caregivers of children treated at UNIMONTES pediatric clinic. Pesqui Bras Odontopediatria Clin Integr 2013; 13(2):189-96. https://doi.org/10.4034/PBOCI.2013.132.08

[19] Beretta RJ, Volpato MES, Galato D, Medeiros GHF. Tooth avulsion from trauma: the level of knowledge of emergency physicians. RFO 2017; 22(1):38-42.

[20] Nagata JY, Góis VLA, Münchow EA, Albuquerque MTP. Dental trauma education intervention as a positive influence among undergraduate students. Eur J Dent 2018; 12(4):502-7. https://doi.org/10.4103/ejd.ejd_148_18

[21] Alyahya L, Alkandari SA, Alajmi S, Alyahya A. Knowledge and sociodemographic determinants of emergency management of dental avulsion among parents in Kuwait: A cross-sectional study. Med Princ Pract 2018; 27(1):5560. https://doi.org/10.1159/000486095

[22] Tzimpoulas N, Markou M, Zioutis V, Tzanetakis GN. A questionnaire-based survey for the evaluation of the knowledge level of primary school teachers on first-aid management of traumatic dental injuries in Athens, Greece. Dent Traumatol 2020; 36(1):41-50. https://doi.org/10.1111/edt.12503 